\title{
Use of Electronic Information Resources by Arts Undergraduates during the Preparation of Final Year Dissertations: A Study at University of Peradeniya
}

\author{
Sunil Premarathne ${ }^{1}$
}

\begin{abstract}
Electronic Information Resources (EIR) perform an important role in the reference resources provided by the academic libraries. Readers are increasingly encouraged to use electronic resources for their research purposes. It is evident that most of the undergraduates consider the library as an important place during their course of study, especially during the preparation of final year dissertations. Therefore, the main objective of the study was to examine the usage of EIR by final year undergraduates during the time of preparation of their dissertation. The study used the survey research design with the application of purposive sampling method. The total population of the final year special degree in Arts students of the Faculty of Arts was 619 in 2014/2015 academic year. A total of 49 final year students of the special degree in Arts who visited the Main Library voluntarily participated in this survey within a period of one month from $01 / 03 / 2015$ to $31 / 03 / 2015$. Descriptive statistical methods were used to analyze the data. The study findings indicated that the students used Internet search engines rather than specialized data bases and fulltext resources to search information. Nearly $88 \%$ of the respondents had never used the library web page to search EIR. Nearly $10 \%$ were familiar with electronic resources available in the library. The main problems associated with non-use of EIR are: lack of skills in information searching and very limited training opportunities and limited facilities in accessing the Internet. According to the findings the reasons for lower usage of electronic resources by undergraduates are the lack of basic skills / knowledge in IT and English language barrier. In order to exploit the full potential of electronic information, university library and the faculty should play active roles by organizing awareness programmes, promoting EIR use among students and develop infrastructure facilities in the Main Library to enhance usage of EIR. Introducing information literacy skills course for students' curricula is recommended to get maximum benefits of EIR Use.
\end{abstract}

Key Words: Electronic information resources, Dissertation, Research, Information seeking

${ }^{1}$ Senior Assistant Librarian, University of Peradeniya, Sri Lanka

E-mail: sp12386@gmail.com

iD http://orcid.org/0000-0002-3987-2215 (c) (P) This work is licensed under a Creative Commons Attribution-Share A like 


\section{Introduction}

University libraries are moving from acquiring traditional information resources to digital information resources. Library automation and the EIR have revolutionized provision of access to information for the library user community. EIR offers the scholars the opportunity to access accurate and current information.

As Ganiyu (2012) also pointed out the electronic information resources can be accessed through Internet in addition to various other means. EIR includes electronic journals, databases electronic books, websites, and subject gateways, etc. Libraries all over the world provide a wide variety of EIR for the use of undergraduates, postgraduates and researchers. Margam (2010) stated that the electronic resources have given us the power to get information timely and manage information more effectively and also the means of dissolving barriers and that it offers equity of access to knowledge and information. Further the EIR facilitate retrieval of information. Today the libraries are moving towards e-resources and computerized services, which are found more useful and easy to use.

According to Togia \& Tsigilis (2009) EIR are valuable tools for study, learning and research. They can provide many advantages as an alternative to traditional print-based resources. These include, availability of current information because they are updated frequently, flexibility in the storage of the results, and ability to access to information without the restrictions on time and location. Most of the higher educational institutions have subscribed to EIR and users can access to these without any barriers. Jodi \& Rachel (2014) mentioned that e-books comprise a significant component of the changing landscape of academic libraries, making it necessary to consider students' use and perception of e-books in collection development decisions. As e-book collections grow, students will encounter an increase in the number of e books and will always have an option to use print books. Thus, in addition to selecting books that are relevant and valuable to students, librarians must also consider the best format needed by the patrons' (Oyedapo \& Ojo, 2013).

Researchers are always using the Internet resources and search engines and EIR have brought radical changes in the way information is gathered, stored, 
organized, accessed, retrieved and consumed in libraries, especially in academic libraries. Most of the libraries are changing their collections from print to electronic resources. They acquire various types of electronic databases in different disciplines meeting the needs of the patrons. The overall objective of academic libraries is to contribute to the teaching role of the parent institutions, to support learning and research activities (Ming-der $\&$ Ssu-Tsen ,2012). University libraries have given their priorities to increase the EIR for decades as their users prefer electronic resources to printed materials.

\section{Existing Electronic Information Resources at the Library Network}

Presently the University of Peradeniya library subscribes to several electronic databases for the use by the staff and students of the University. While Internet facilities are available through the library access to these databases is provided either through IP address or user name/ password can be used only within the university network. The subscribed electronic resources are protected under copyright law and publisher's license agreements. Open Access resources and some other important websites are also available through library website. The E resources relevant to the Arts and Humanities undergraduates are as follows; SAGE Research Methods, Emerald, Taylor and Francis, Wiley (Online Library), JSTOR, DOAJ, and SLJOL etc... Awareness programmes on library facilities and the Eresources are provided by the library on a regular basis.

Although the library is equipped with these facilities and EIR, it is evident that undergraduates have not used them effectively. This has been endorsed by the findings of the following studies, Hindagolla 2017; Hindagolla \& Nakamura 2015; Alahakoon, 2014; Alahakoon \& Jayasundara, 2014; Gunasekara 2011; Gunasekera, 2010. The purpose of this study is to try and identify the reasons for such low usage of these resources by undergraduates for their academic purposes. The study mainly focused on final year special degree progrmme as they are supposed to submit a dissertation in their final year. For this purpose students are required to find relevant articles through a literature search using library resources. 


\section{Objectives:}

Main Objective of the study is to examine the usage of EIR by Arts undergraduates during the preparation of the final year dissertations and identify the challenges faced in the use of EIR by the undergraduates.

\section{Methodology}

Survey design was used for this study and purposive sampling method was applied. Data was collected from final year Art undergraduates attached to the Faculty of Arts, University of Peradeniya. The total population of the final year special degree students of the Faculty of Arts was 619 in 2014/2015 academic year. Students were selected using purposive sampling method and a total of 49 final year students who visited the Main Library between $01^{\text {st }}$ March 2015 to $01^{\text {st }}$ May 2015 were taken as sample of this case study.

A questionnaire was administrated to gather information about the computer skills, language skills, purpose of Internet use, satisfaction on library web page, and major obstacles to access EIR. The data was analyzed using descriptive statistical methods

\section{Results and Discussion}

The researcher managed to collect 49 completed questionnaires as responses. The students had some difficulties to access the electronic resources as inadequate computer knowledge. Therefore the researcher planned to get self assessment of computer skills of the respondents. The table no 1 shows a clear picture of the skills on computer usage of the respondents. It was revealed that more than $55 \%$ of the students had the average ability to manage with basics of computer operation, word processing, spread sheet/excel, accessing of Internet and e-mail, competency on social network. However, the usage of databases is not at a satisfactory level. 
Table 1: Self Assessment of Skills on Computer Usage \& EIR usage

\begin{tabular}{|c|c|c|c|c|c|c|}
\hline & 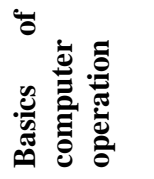 & 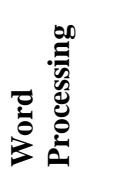 & 这 & 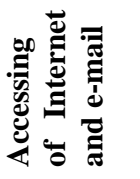 & 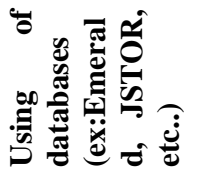 & 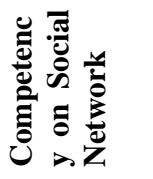 \\
\hline Poor & $2 \%$ & $2 \%$ & $0 \%$ & $4 \%$ & $18 \%$ & $6 \%$ \\
\hline Fair & $10 \%$ & $8 \%$ & $32 \%$ & $14 \%$ & $24 \%$ & $14 \%$ \\
\hline Good & $56 \%$ & $68 \%$ & $58 \%$ & $62 \%$ & $38 \%$ & $56 \%$ \\
\hline $\begin{array}{l}\text { Very } \\
\text { Good } \\
\end{array}$ & $28 \%$ & $18 \%$ & $8 \%$ & $16 \%$ & $18 \%$ & $18 \%$ \\
\hline $\begin{array}{l}\text { Excellen } \\
\mathrm{t}\end{array}$ & $4 \%$ & $4 \%$ & $0 \%$ & $4 \%$ & $2 \%$ & $6 \%$ \\
\hline Total & $100 \%$ & $100 \%$ & $100 \%$ & $100 \%$ & $100 \%$ & $100 \%$ \\
\hline
\end{tabular}

According to figure no 1, it was revealed that $88 \%$ of students were searching full text articles via search engines. About 50\% of students' use Google Scholar for their information searching. However, only $36 \%$ of them access full text articles through university library scholarly data bases. It is indicated that they have given less attention to the scholarly databases that provide access by the library.

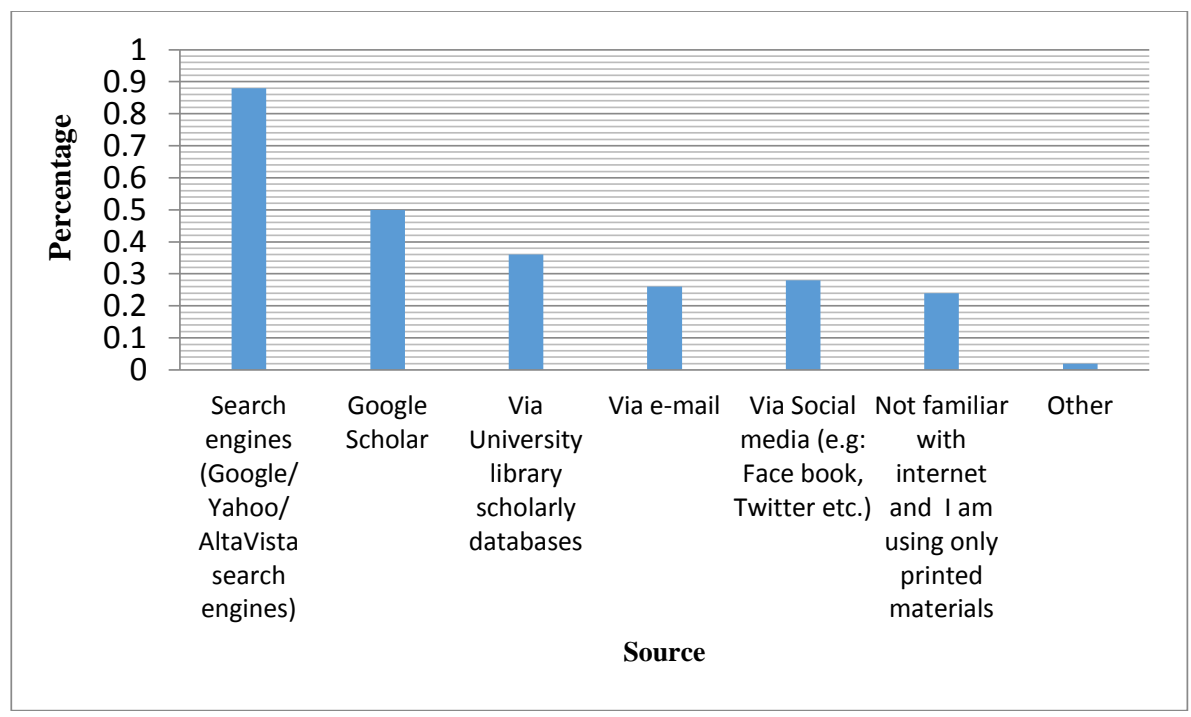

\section{Figure 1: Search Full Text Articles via Internet}

Respondents were asked of the purpose of using the Internet during their study period. Majority of them $(75 \%)$ responded that they use internet for finding information for the preparation of assignments and for writing 
dissertations. Further, the respondents were asked whether, they were aware of e-journals and databases provided by the library. Majority of respondents $(60 \%)$ mentioned that they were not familiar with library web page and eresources available. It was revealed that they were using internet for their studying purposes but desired to get train on using other databases as well. Majority of students (80\%) mentioned that they have been guided by their friends to use the internet and $72 \%$ of them reported that they did not receive any proper training on EIR use in the library. Therefore, proper awareness programs and training is required for the undergraduates.

\section{Satisfactions of Electronic Information Resources provided by the Library}

Figure 2 indicates the undergraduates' satisfaction of EIR provided by the library. $48 \%$ of respondents were not satisfied with the EIR provided the library. Undergraduates have uncertain idea of electronic information resources are easy to use.

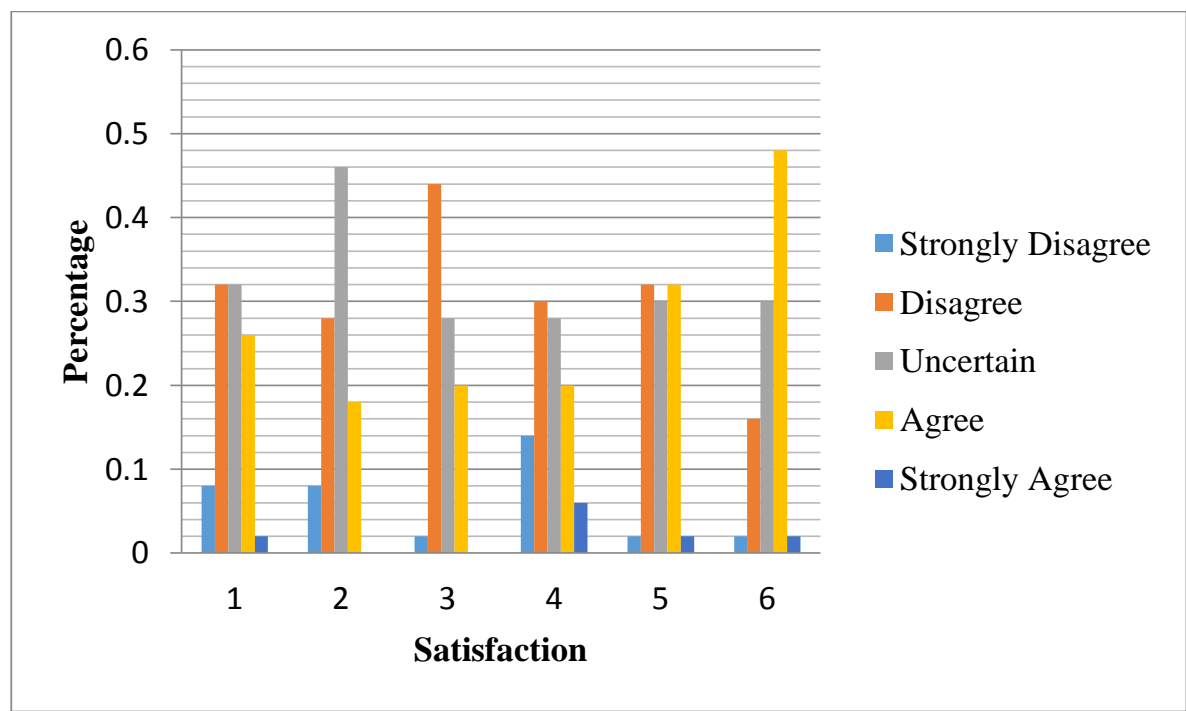

(1: Overall, I am satisfied with electronic resources provided by the library, 2: Electronic Information Resources are easy to use,3: If I had problems in using electronic resources, I was quickly able to resolve them, 4: Library staff were helpful in telling me how to use the libraries' electronic library resources, 5: It is easy to access the electronic library resources via library web page, 6: I am not satisfied with the electronic resources provided by the library)

Figure 2: Satisfaction of EIR provided by the Library 


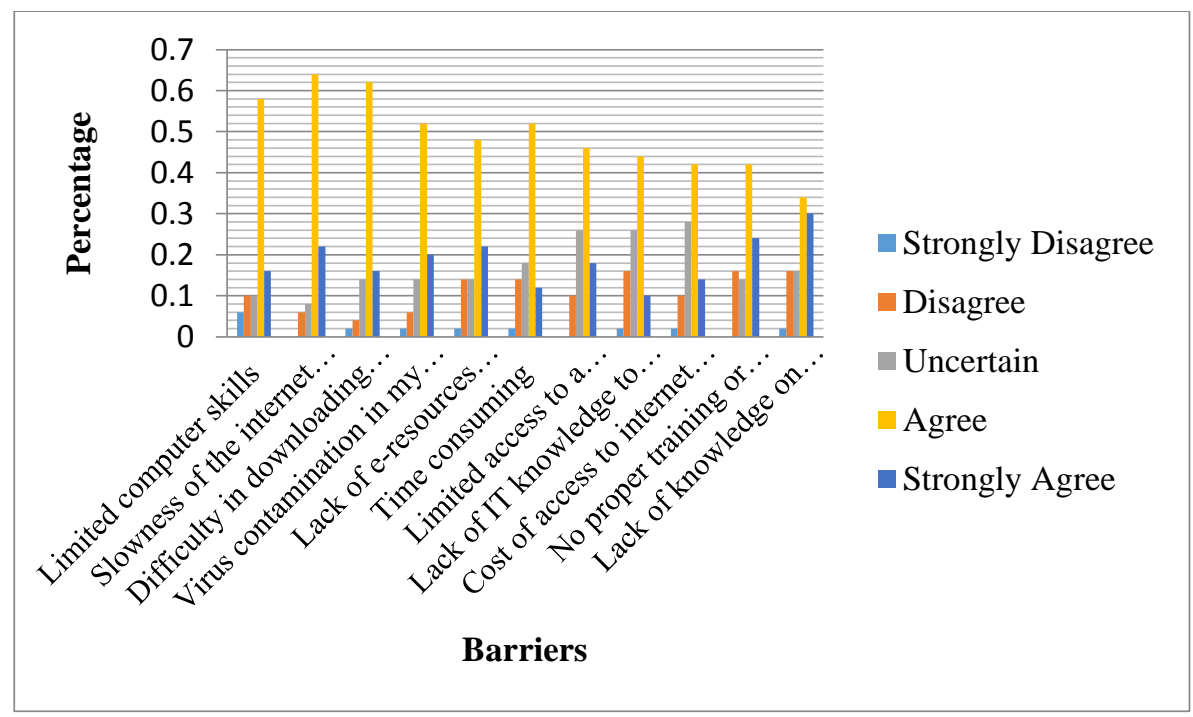

Figure 3: Barriers to Use EIR

All the respondents have mentioned obstacles encountered when using (figure 03) EIR, such as lack of necessary computer skills, slowness of the internet connectivity, difficulty in downloading articles from the internet, virus contamination in saving devices, lack of e-resources relevant to their research, time consuming, limited access to a computer terminal, lack of IT knowledge to effectively utilize the services, no proper training or guidance given by the library on how to use these resources, lack of knowledge of English language. The students have agreed with the above barriers that affect the access to EIR and the library staff should consider them as important factors to be concern.

The study findings identified the suggestions pointed by the respondents, for the library management and the faculty staff to focus their attention in future training programs on EIR.

1).Need of proper guidance prorammes on how to use electronic resources, to get up to date information for our academic work.

2). We suggest that library staff should get involved in training us to use the e-resources. 
3). We are not aware of the availability of these materials. To organizing awareness programmes for each department is a timely important measure.

4). Increase the number of computers in the main library and establish an ezone.

5).Conduct training programs on EIR that are available in the library.

6). Very limited numbers of computers are allocated to the students. There should be special training sessions to use EIR before writing the dissertation.

7). Practical training need on IT and training to maintain computers should be given to first year to final year students.

8). Faculty and library staff should work together when arranging training programs on EIR.

Library staff can play an important role by educating not only the students, but academics as well, who will in turn pass the information to their students and encourage them to consult digital resources for study and course-related assignments. Another effective way for students to learn about important resources in academic libraries is to give an opportunity for librarians work directly with students and academics to bring relevant electronic resources into the classroom or at department level.

\section{Conclusion and Recommendations}

Based on the findings, the study concluded that the use of EIR by the final year undergraduates for preparation of dissertation is underutilized. They depend on only search engines to find information. They are not familiar with the library web page. They also depend on printed journals than the electronic databases. It has been observed the undergraduates often experience difficulties in searching and using information effectively. Lack of information literacy skills is seen to be the searching difficulties. The large number of students does not use the EIR properly in the preparation of dissertations and also they leave the University without the necessary knowledge, skills on EIR to cope within information based society. Therefore, they need to acquire more skills in the use of EIR. Major challenges of the students to use the EIR are found to be limited computer facilities, lack of any training, language barrier to use these resources, 
limited encouragement to use these resources. Students have a good knowledge to operate computers but they should have more awareness on the use of EIR. The faculty and the library managers should introduce the information literacy skills programmes for the first year up to final year. Those should be made compulsory programmes incorporated into credit base system.

Following recommendations are made: based on the above findings

- EIR should be adequately organized and made available for easy access and the computers available in the Library, faculties, IT Center should be improved.

- There should be continuous training for library staff and faculty on how to maximize the use of e-resources available in the library. The faculty and the library managers should consider introducing of Information Literacy Skills programmes for the students.

- There should be more provisions for information technologies that will facilitate information searching and also an electronic document delivery services should be introduced.

- Library management should have a strategic plan on how to best to showcase e-resource collections of the library in order to attract more patronage and hence be more relevant in this information provision. Library management should provide adequate funds for subscription of e-resources.

- Supervisors should encourage the final year students to use the available EIR in library websites.

\section{Reference}

Alahakoon, Champa N. K. (2014). Factors contribute to the usage of library electronic information resources (EIR) by university students in Sri Lanka." In: Proceedings of the $5^{\text {th }}$ International Conference on Libraries, Information and Society (217-230) 4-5 November, 2014, Kulala Lumpur, Malaysia.

Alahakoon. Champa N. K. \& Jayasundara, C. C. (2014). Use of Electronic 
Information Resources and the training needs of undergraduates of HSS. In :Proceedings of the ULA Academic Sessions2014((25). $6^{\text {th }}$ February 2015, University of Ruhuna,

Gunasekera, Chamani. (2010). Students usage of an academic library: A user survey conducted at the Main Library University of Peradeniya. Journal of the University Librarians Association of Sri Lanka. 14(June 2010), 43-60.

Gunasekera, Chamani (2011) Information needs and usage pattern of Undergraduates: Comparative study, Information Age, 5 (3-4), 20-25

Hindagolla, Menaka (2017).'The use of Digital Library by Arts undergraduates in Sri Lanka: A case study at University of Peradeniya".In: Proceedings of the $17^{\text {th }}$ International Conference of Social Science and Humanities (38), Asian Institute of Thailand, Bangkok, 18-19 July, 2017

Hindagolla, B.M.M.C.B \& Nakamura, T. (2015). Impact of intrinsic and extrinsic motivation on Digital Repository usage by undergraduates, In : Proceedings of Peradeniya University International Research Sessions (451), University of Peradeniya, Sri Lanka. $5^{\text {th }}-6^{\text {th }}$ November 2015.

Ganiyu, O. Q. (2012). Impact of ICT Skills on the Use of E-Resources by Information Professionals: A Review of Related Literature, Library Philosophy and Practice (e-journal), Retrieved from http://www.unllib.unl.edu/LPP/762

Jodi, S. \& Rachel, A. (2014). Social Work Students and E-Books: A Survey of Use and Perception. Behavioral \& Social Sciences Librarian, $33,15-28$.

Margam, M. (2010).Use of electronic resources by research scholars of Kurukshetra University, The Electronic Library, 28 (4), 492. 
Ming-der, W. \& Ssu-Tsen, Y. (2012). Effects of Undergraduate Student Computer Competence onUsage of Library Electronic Collections, Journal of Library and Information Studies 10 (1),1-17

Oyedapo, R. O. \& Ojo, R. A. (2013). A Survey of the Use of Electronic Resources in Hezekiah Oluwasanmi Library, Obafemi Awolowo University, Ile-Ife, Nigeria, Library Philosophy and Practice (ejournal).884. Retrieved from http://www.digital commonsunl.edu/libphilprac/884.

Rohleder, P. \& Bozalek ,V. (2008). Students' evaluation of the use of elearning in a collective project between two south African Universities. Higher education, 56(01), 95-107.

Togia, A. \& Tsigilis N. (2009). Awareness and use of electronic information resources by education graduate students: Preliminary results from the Aristotle University of Thessaloniki. QQML2009: Qualitative and Quantitative Methods in Libraries, International Conference, Chania Crete Greece. 26-29 May 